\title{
Qualification reference book and teacher professional standard cancellation justification
}

\author{
Denis Dmitriev ${ }^{1, *}$, Natalia Solovova ${ }^{1}$, Almira Galimova ${ }^{1}$, Marina Belinskaya ${ }^{1}$ \\ ${ }^{1}$ Samara National Research University, Moskovskoe shosse, 34, 443086, Samara, Russia
}

\begin{abstract}
The research is about the Russian qualification reference book and the Russian professional standard "Professional training, professional education and additional professional education teacher" comparison. The Russian professional educational standard was analyzed and main reasons of it's cancelling were determined and described. The basis of the article is the educational society ambiguous attitude to the professional standard introduction. The Russian professional standard "Professional training, professional education and additional professional education teacher" main principles were dismantled. The main differences of the Russian qualification reference book and the Russian professional standard were given. In the process of this comparison the weak points of professional standard were determined and described. The other researchers and teaching staff attitude the Russian professional standard introduction were also reflected in this article. The professional standard launch cancellation was justified. That is why there are detected main disadvantages of the qualification reference book and these modern and actual stayed. Based on this the conclusion was made that new legal regulatory document is urgently needed. But planned professional standard was underdeveloped.
\end{abstract}

\section{Introduction}

One of the main strategic goals of the Russian Federation state program "Education development for 2013-2020" (№ 376 dated 31.03.2017) is to ensure the Russian education quality and the scientific and pedagogical workers qualifications conformity to the current regulatory requirements and the unified qualification reference book $(\mathrm{QRB})$. That should address the innovative economy and post-industrial society priority tasks. The need to address personnel issues is a condition for education system management improving and is indicated in the current Federal target programs for the education transformation and development. Any educational organization main activity is the educational programs implementation, which consists in the educational activities implementation [1]. Teachers are directly involved in educational activities. Currently, there are a number of changes in the legal framework concerning additional requirements for this category of educational organization employees. Therefore the object of the research is scientific and pedagogical workers (SPW) socio-economic and socio-labor relations. The main contradiction is that in

\footnotetext{
* Corresponding author: denisdmitriev000@gmail.com
} 
the terms of higher education organization teaching staff personnel risks emergence with the need to transit to the new legal documents there are not any these requirements compliance correctness practical recommendations when implementing educational programs. There are also no regulatory conflicts related to educational activities staffing.

\section{Materials and methods}

The material is based on the theoretical research methods application: the Russian Federation legal acts in the education field and scientific literature on the research subject analysis; system analysis; logical social processes modeling, on the basis of which the study initial theoretical provisions and its main concepts are determined. The presented research empirical results are: classification the documentation; the obtained results analysis.

\section{Results}

Most of the Russian higher education organization employees are scientific and pedagogical workers (SPW). Till recently the SPW activity was regulated by Russian Federation several regulatory acts, such as Russian Federation Education Law (№273 dated 29.12.2012) and QRB. In addition to the above-mentioned legal documents, various professional standards are planned to come into effect, some of which update the professional education teacher requirements [2]. According to article 50 Education Law, higher education organizations provide the teachers and researchers positions, which make up the SPW group. Researchers can be members of the educational organization collegial management entities, take part in the educational organization activities regulating, choose of scientific research conducting methods and means, and use educational organization educational, methodological and scientific services free of charge. Their activities are aimed at students' professional qualities development and their independence, initiative and creative abilities improvement. Teaching staff belong to the qualification category, in relation to which qualifications additional requirements mentioned in professional and educational standards are developed. So, according to the $\mathrm{QRB}$, the following positions belong to the teaching staff: assistant, lecturer, senior lecturer, Associate Professor, professor, Department head, Faculty Dean (Institute Director).

Article 52 of the Labour code establishes this employees category right to engage in teaching activities and this activity suspension features. It also contains the conclusion and termination peculiarities of the employment contract with faculty, including additional grounds for the employment contract termination and the working time duration, the right to annual basic extended paid leave. The Russian Federation Ministry of Education and science Order №. 1536 dated 04.12.2014 "On approval of the Regulations on the procedure for scientific and pedagogical workers positions filling" defines the positions filling procedure and conditions for SPW (teaching staff, researchers) and concluding employment contracts with them for an indefinite period or for a certain period not over more five years. The activity of teaching staff of higher education organization is regulated by the Federal state educational standard of higher education (FSES). FSES is the set of mandatory implementation requirements of the basic educational programs by higher educational state accredited organizations. FSES includes a number of requirements for the various levels educational programs implementation (bachelor's, specialist's, master's, etc.), among which there are personnel conditions requirements of educational program realization, that is, the skill level and number of involved professional teaching staff.

At the same time, in addition to Federal regulations, there are also a number of lowerlevel documents that are also part of the regulatory framework for regulating social and labor 
relations of PTS from the SEW. So, at the level of the educational organization, the regulation of social-labour relations under the SEW, and in particular PTS, is the Charter of the educational organization, Collective agreement, internal regulations and other local normative acts. Thus, the SEW socio-labor relations are regulated by a number of certain legal acts. Requirements for PTS, until 2020, were mainly formed by QRB provisions. In the context of the transition to new regulations (professional standards), a number of new requirements for PTS compliance are introduced. That, accordingly, like any changes, may lead to socio-labor relations changes that can provoke the new personnel risks emergence.

In the modern conditions of global digitalization the Russian higher education system is constantly improving: national programs are being implemented, information and communication innovations are being introduced, and online learning is developing. In this regard, there is a growing need for highly qualified staff among teachers who can adapt to changes and constantly learn new skills, thereby meeting the needs of modern society. The professional standard "Professional training, professional education and additional professional education teacher" was developed in order to improve the qualification level of higher education organizations employees who are directly involved in the educational process, namely, teaching staff. At the same time, the QRB also applies to the teaching staff qualification requirements, the qualification requirements and job responsibilities of which were described earlier. It was planned that the professional standard should replace the QRB in the future, but the need to comply with two regulatory documents requirements created difficulties in the educational organizations work.

These regulations have a number of different and similar provisions. So, both in the professional standard and in the QRB, the scope of application is labor functions, labor actions, and requirements for the education and training of employees from among the teaching staff. The content of the documents also has similar features and includes powers and responsibilities, the nature of skills, the nature of knowledge, and the main ways to achieve the level of qualification of employees from among the teaching staff. It is worth noting that for the first time in the teaching staff requirements there is a need for additional education and professional retraining.

The senior teacher position requirements, if the employee has a $\mathrm{PhD}$ degree, they must have at least 1 year of scientific and pedagogical work experience. In the professional standard provisions, there were no requirements for work experience in this situation. If an employee who is holding the position of associate professor has an academic title, the professional standard did not have work experience requirements, whereas in the QRB, the scientific and pedagogical work experience must be at least 3 years. In addition, according to the professional standard provisions, an associate professor has the right to direct the activities of students in practice.

For the positions of the Department head and the Faculty Dean (Institute Director), the professional standard did not specify special compliance requirements, so these positions were not studied in detail in this research. Since the previously planned conditions for to the professional standard switching were new for organizations, not previously tested and insufficiently studied a number of other explanatory regulatory documents were attached in addition to the professional standard itself. It was made to help the professional standard provisions applying.

The main issue for employers was the regulatory framework for the professional standards application. The letter of the All-Russian Trade Union of education № 122 dated 10.03.2017 explains that the fundamental and other normative legal acts in the professional standard application are: article 5 of the Russian Federation labor code; article 57 of the Russian Federation labor code; part 1 of article 195.3 TC RF of the Russian Federation labor code; the resolution of the Russian Federation government № 584 dated 27.06.2016 "On peculiarities of professional standards application in requirements terms, obligatory for 
application to the state extra budgetary funds of the Russian Federation, state or municipal institutions, state or municipal unitary enterprises and state corporations, state companies and economic entities, more than fifty percent of shares (stakes) in the authorized capital of which is state-owned or municipal property" (hereinafter - Resolution). The Resolution specifies the measures completion date to establish the teaching staff compliance with the professional standard requirements, which is set for January 1, 2020. Prior to this period, each higher education organization gradually implemented an independently developed action plan, which contained: the professional standards list to be applied; information about the employees professional education, professional training and (or) additional professional education need and about the appropriate measures implementation; the professional standard applying stages; a list of local regulations and other documents subject to change, taking into account the provisions of the professional standard.

The Russian Federation Labor Ministry Letter № 14-3/B-57 dated 31.01.2017 explains that the professional standard specifies the employee minimum requirements, and an employee with the higher qualification level, has the right to perform work duties. At the same time, the responsibility and authority to make personnel decisions in the transition professional standard conditions are the powers of employers. It should be noted that if the employee is granted benefits, compensation, or there are restrictions on the work performance, then infringement of the employee's rights in this case is unacceptable. At the same time, in the conditions of professional standard transition, the heads of educational organizations had a problem with this document definitions and basic concepts. For example, according to article 195.1 of the Russian Federation Labor code, the employee's work experience, level of knowledge, professional skills constitute the employee qualification definition. Herewith, in the Federal Education Law, a qualification is defined as the employee level of knowledge, skills, and competencies. In turn, the term "work experience" is not included in the above-mentioned regulations.

Although labor legislation includes work experience in the concept of "qualification", the Education Law includes the concept of "competence "instead of work experience in the "qualification" concept. The Letter of the Russian Federation Labor Ministry № 14-2/OOG3725 dated 28.05.2019 explains that work experience should be understood as a set of practically acquired knowledge, skills and abilities in this professional activity, and gives the Manager the subjective right to evaluate this criterion. This issue is resolved by the letter of the Russian Federation Education and Science Ministry № 03/7480-o dated 28.06.2019, which defines the term "competence" as knowledge, skills and production experience applied and improved in specific conditions, and "qualification" as the official expression of employee technical or professional skills. Also, in the conditions of the professional standard transition, the question about the teacher education mandatory need for each employee from among the teaching staff arose [3]. The letter of the Education and Science Ministry № 03/8750-o explains that employees from the teaching staff are not required to undergo professional retraining in pedagogy. At the same time, training in additional professional programs in the profile of pedagogical activity was recommended to be underwent at least once every three years. The measures implementation time frame to establish compliance with the teaching staff professional standard requirements is set for January 1, 2020. According to the Education Law, additional professional education is aimed at meeting person educational and professional needs, professional development, ensuring that their qualifications meet the professional activity and social environment changing conditions. Additional professional education is carried out through the implementation of additional professional programs (advanced training programs and professional retraining programs). Professional retraining programs are developed on the established qualification requirements, professional standards and requirements of the FSES development of educational programs basis. According to the Letter of Department of State Policy in the education sphere of 
Education and Science Ministry and the Russian trade Union of education № 08-415/124 dated 23.03.2015 to create the conditions for the employees additional professional education as the settlement of not only organizational, but also financial issues directly related to next moments, including: provision of guarantees and compensations established by labor legislation and other regulatory legal acts containing labor law norms, collective agreements, agreements, local regulations, and employment contracts; sending an employee for training at the expense of Federal budget allocations, budgets of the constituent entities of the Russian Federation, or paying for the employee training enrolled in training at the expense of the organization's funds provided for these purposes.

The organization (employer), on the terms and in the manner determined by collective agreement, agreements, the labor contract (article 196 of the Labor code) have the right to determine the need for employees additional professional education for its own needs. At the same time, the employer does not have the right to oblige employees to carry out APE at their own expense. Refusal of an employee from the number of teaching staff in such cases will be a disciplinary offense. For the Commission of this offense, the employer has the right to apply the appropriate disciplinary penalty provided for in article 192 of the Russian Federation Labor code.

The professional standards introduction has become an urgent topic for modern research, causing a mixed reaction [4]. Thus, N. V. Lebedeva believes that professional standards are focused, to a greater extent, on the high school teacher personal qualities development. Based on the professional standard analysis, the author highlights that the teacher priority competencies include motivation development psychological and methodological foundations knowledge, labor psychology basics knowledge, stages of professional development, effective communication methods and activities organization aimed at supporting professional adaptation, professional development of students and their professional self-determination. According to the author, "the high school teacher knowledge of responsibility measures for the life and health of students under his supervision" has great importance.

O. G. Krasnoshlykova, G. T. Vasilchuk talk about the introduction of professional standards, which will radically affect the process of future teachers training, as a complex process that requires the additional mechanisms creation. The authors are convinced that an important role in teacher training can be played by a continuous training system that allows teachers' professional deficits recognizing and correcting in accordance with changing requirements. In turn, L. A. Shipilina, from her point of view, describes the changes concerning the personnel management system, and in particular, the personnel policy in high education organizations in the conditions of professional standard transition. According to the author, the professional standards introduction has a positive impact on the educational organizations activities and the personnel management system, establishing certainty in areas where there were previously inaccuracies and uncertainties. At the same time, the author highlights possible personnel risks that arise in to the professional standard transition. Among them, the non-acceptance of the term "standard", which excludes creativity and freedom; excessive requirements may be beyond the power of an ordinary person, and some may physically, and to a greater extent, psychologically fail to cope with them; many see the professional standard as a way to manipulate teachers from the University administration. The main reason for the occurrence of the above-mentioned personnel risks, the author calls the lack of readiness for changes.

Professor A. K. Bykov also believes that professional standards inevitably and to varying degrees affect the University personnel policy, and in particular - there are changes in each subsystem of personnel management. The author gives recommendations to teaching staff, which, in his opinion, contribute to a deeper understanding of the professional standard, as well as help protect teachers from illegal actions on the part of the University management. 
L. G. Zvereva, A.V. Nikitina, and E. G. Avanesyan believe that the emergence of a multilevel system of qualifications, namely, the division into bachelor's and master's degrees, led to the formation of new requirements for teaching staff. The authors highlight the main problem is the behavioral changes trends insufficient knowledge in the personnel policy implemented by universities, as well as the assessment of the institutional changes influence degree on the essence and content of personnel policies various models. They note the importance of having both traditional and new technologies in the personnel policy of a modern University. With the help of various programs and activities implementation, the University can be selected to apply a combination of the best and most effective strategies. On the pages of the magazine about modern high-tech pedagogical technologies, A. L. Kobleva notes the main problem of modern education, namely, the new professional competencies development for teachers dictated by the demands of time. They are the competencies dictated by time requests and reflected in the professional standard. For example, "the ability to self-organization and self-education" (OC-6),"readiness for professional activity in accordance with the legal documents of the education field" (OPC4), or "the ability to design the trajectory of their professional growth and personal development" (PC-10). According to the results of the author's research, a low level of receptivity to new things was revealed among teachers, as well as a low level of motivation. However, A. L. Kobleva explains the innovations inevitability in the additional professional pedagogical education system and the development innovative forms transition of teacher professional competence. A. I. Satdykov, S. A. Osadcheva and L. N. Kurteeva published a separate explanatory article on the teacher professional standard use. The article reflects the position of the professional standard developers, the main directions for finalizing the document that are currently underway, as well as existing contradictions in legislation that create conflicts in law enforcement practice, and suggests ways to resolve them.

In General, the authors emphasize the role of professional standards as "a bar of modern requirements and guidelines for building personnel policy", and not a way to complicate professional activities for teachers and management, the myth of which has developed among many people involved in this topic in one way or another. The special importance of this scientific article is expressed by the of the legislative contradictions existence recognition in the application of the professional standard and information about planned changes to the professional standard in 2020. A. N. Krylov considering the generalized professional standard labor function, considers this document asone of the most difficult to apply out of more than 800 professional standards. Therefore, based on the results of the analysis, the author puts forward the idea of the expediency the professional standard dividing for additional professional education, professional training and professional education teachers.

\section{Discussion}

Thus, in the terms of the educational system modernization a large number of contradictions and uncertainties sharp reactions and, as a result, disputes and proposals. It is worth noting that each of the authors who raise the professional standard implementing issue, in one way or another, touches on the problem of teaching staff unavailability to changes, insufficient information and technical base and rather high requirements. This situation clearly demonstrates the regulatory requirements uncertainty for the personnel support quality for educational programs and emerging personnel risks, which once again shows the study relevance of and the obtained results significance. The analysis shows that the professional standard introduction cancellation "Professional training, professional education and additional professional education teacher" is justified. At the same time, there are a number of acute objective reasons for the QRB criticism existence, which again become relevant in connection with the professional standard abolition. The position remains unclear in relation 
to the teacher education requirements in the educational programs implementation, which was clearly proposed to be solved in the teacher professional activities implementation. There is still a problem with the legitimacy of the certification commissions work, since certification is possible only under the indefinite employment contract condition; the problem of employers representatives employment for the of the educational program implementation and the educational standard requirements (in compliance with statutory requirements the degree availability and the need to attract employers to the program implementation); the need for work experience for at least one year of employment for the position of assistant and others.

\section{Conclusion}

Thus, in the terms of the educational system modernization a large number of contradictions and uncertainties sharp reactions and, as a result, disputes and proposals. It is worth noting that each of the authors who raise the professional standard implementing issue, in one way or another, touches on the problem of teaching staff unavailability to changes, Meeting the requirements for teaching staff and managing the SPW risks that arise when it is necessary to comply with the requirements of various regulatory categories has become personnel management essential element in a modern educational organization. At the same time, professional standards, QRB and FSES are highlighted as the main legal documents that contain requirements for the employees qualification who hold teaching staff positions. Contradictions between them were revealed, innovations and features which were dictated by the professional standard provisions that justified the professional standard requirements cancellation were analyzed. The main contradiction lies in the differences in the employees labor functions from the number of PTS. Based on the analysis of modern researchers various opinions, it was concluded that it is necessary to introduce regulatory changes in the higher education system, and the main difficulties and concerns associated with the professional standards transition were identified. The problems updating related to compliance with the QRB requirements still creates a uncertainty state about compliance with a number of requirements and the need for clarification and additional legal acts that contribute to the educational programs quality implementation.

\section{References}

1. L. Valeeva, Procedia - Social and Behavioral Science 191, 2312-2315 (2015)

2. D. Kosyakov, A. Guskov, Procedia Computer Science 146, 60-71 (2019)

3. N. Paufler, Studies in Educational Evaluation 64, 1-15 (2019)

4. T. Bourke, M. Ryan, P. Ould, Teaching and Teacher Education 75, 83-92 (2018)

5. Studies in Educational Evaluation 64, 1-15 (2019) 